special problems undertaken for the Commission by universities and other institutions.

Much of the work of the Commission's own research branch is devoted to the trying out of various treatments and techniques on the growth of seedlings and young plants in the nursery and in the forest. Some of the more fundamental problems in connexion with such treatments are dealt with by workers in various institutions. An example of this is the effect of partial sterilization of the soil of established nurseries on the growth and survival of seedlings. It has been found that the residual effects of steriliza. tion by steam and by formalin in the previous year are marked, and experiments are being made with the view of improving the methods of applying formalin to improve the effectiveness of the chemical. J. H. Warcup, of the Botany School, Cambridge, presents some interesting results of the effect of partial sterilization by steam and formalin on the fungal population of the soil at Ampthill Nursery, Bedfordshire, where the response of sitka spruce seedlings to sterilization was very large. Before sterilization, the soils were found to contain more than a hundred species of fungi. In the steamed plots all fungi were killed down to a depth of about twelve inches, and in the formalin plots down to four to six inches. Re. infection started from the surface in about six weeks in the steamed plots and nine weeks in the formalin plots. Re-infection was mainly by Trichoderma viride in the formalin plots. In the steamed plots, Trichoderma was the commonest species to reappear, with Mortierella and Coniothyrium as associates.

A very interesting section of the report is that on forest genetics, by the Commission's geneticist, J. D. Matthews. The ultimate object of the work is, of course, to provide British foresters with supplies of seed which will produce trees of desirable qualities, whether in form, resistance to disease or insect attack, vigour of growth, etc. This is a long-term project which is divided into three stages in its progress towards complete control of parentage. The first step is mass selection. The best stands in the country are being listed by means of the Census of Woodlands for 1947. The older woods are regarded as safe sources of seed, after the obviously bad trees are removed. Younger woods of unknown origin will be tested by observations on plantations formed of their progeny. By this method the parent trees are known only in mass. The second stage is the selection of mother trees. Vigorous and well-formed mother trees have been selected in the best of the older woodlands and plantations, and seed will be gathered from them during several successive years. The progeny will then be tested against a standard race, and 'seed plantations' will be formed from offspring of the best parents. The mother trees are now known, while the fathers are unknown. The third stage is the testing out of outstanding phenotypes by vegetative propagation and controlled pollination. The trees with outstanding genotypic constitution will be included in a series of 'seed orchards' and treated for regular seed production in a similar manner to fruit orchards. Both male and female parents are now of known value. In the report, the progress made with each of the important species used in British forestry is described, and mention is also made of experiments to improve the technique of vegetative propagation. Testing of kinds of stocks and scions for grafting different species, the use of various growth substances to promote the rooting of cuttings, etc., and the search for methods of hastening seed bearing are all receiving attention.

In the section on forest ecology, by J. M. B. Brown, four outstanding beech forests in England are described, with special reference to the natural regeneration. Exposure to wind, which removes the litter and dries the surface soil, hinders or prevents beech regeneration; and generally speaking, regeneration in large gaps is poor or absent, while in smaller openings it is successful. It is clear, from these and other beech woods, that good beech can be grown in Britain under widely different conditions, and one of the conclusions reached is that the $p \mathrm{H}$. of the soil is, of itself, not a decisive factor. Of eighteen of the finest stands of beech in Britain with mean top heights of $100 \mathrm{ft}$. or more, three were definitely on soils with a $p \mathrm{H}$ less than 4.9 (class 1 ) ; two more were in the same class of $p \mathbf{H}$ but on the border-line of the next class; one was in class $2(p \mathrm{H} 4 \cdot 5-5 \cdot 9)$; eight in class $3(p \mathrm{H} 6 \cdot 0-7 \cdot 9)$; and four in class $4(p \mathrm{H}$ more than 8). Attention is, however, directed to the possibility that the influence of the beech canopy on the soil over a period of a hundred and fifty years or more may have caused changes, so that it cannot be assumed that the present $p \mathrm{H}$ of the soil represents the condition in which the forest actually grew up.

It is impossible to mention all the different subjects covered by the report dealing with forest research ; it is especially valuable to forestry workers, but some topics are of interest to biologists and soil scientists generally. In general, the report is valuable because it mentions many of the problems and difficulties with which the British forester is faced and the steps which are being taken to deal with them by sylviculturists, engineers, economists and scientific workers in various fiolds.

T. Thomson

\section{ISOTOPES IN MICROBIOLOGY}

U DER the chairmanship of Dr. A. J. Amos, the Industry organized a symposium "Is Microbiology" which was held at the Institution of Structural Engineers, London, on October 10. In an effort to present the possibilities of tracer technique to those working in both the industrial and academic fields, the papers covered a wide range, from general reviews of the technique and its results to specialized accounts of individual research problems.

Dr. J. C. Boursnell opened the meeting with a paper on "General Aspects of the Use of Radioactive Iso. topes in Biology". Starting from an elementary treatment of the physics and chemistry of radioisotopes, emphasis was laid on the practical consequences of these facts : on the importance of paying attention to counter geometry and its reproducibility, and on the effects of sample thickness when working with soft $\beta$-emitters such as sulphur-35 and carbon-14. So far as precautions against radioactive hazards are concerned, he said there is much to be gained by working rapidly and at a distance from the sample as well as by adequate screening.

Dr. R. Davies reviewed "The Applications of Radioisotopes in Microbiological Chemistry", illustrating the technique of identifying intermediate compounds and of estimating the order of their appearance in a sequence by reference to the work of Calvin and Gaffron on carbon dioxide fixation by Scenedesmus, and to that of Burris and Wilson on 
nitrogen fixation. The studies by Spiegelman on phosphate turnover in the nucleoprotein fraction of yeast during growth, but not during glycolysis, were commented upon, followed by a more extensive consideration of reaction systems in equilibrium.

The simple picture of equivalence of specific activity among the labelled reactive groups participating in a reversible reaction at equilibrium may break down not only in cases where too little time is allowed to achieve equilibrium, but also where alternative reaction routes exist, where the isotope is transferred by some other reaction, or where the system for the reverse reaction is not complete. An excellent example of such difficulties is provided by the studies of Wood, Werkman et al. on the phosphorylative decomposition of pyruvic acid into formic acid by $E$. coli. The reaction

$\mathrm{CH}_{3} \mathrm{CO} . \mathrm{COOH}+\mathrm{H}_{3} \mathrm{PO}_{4} \mathrm{CH}_{8} \rightarrow$ COO. $\mathrm{PO}_{8} \mathrm{H}_{2}+\mathrm{H} . \mathrm{COOH}$ is apparently reversible if judged by the attainment of equal specific activity in the carbon-14-labelled carboxyl groups, but added carbon-13-labelled acetyl phosphate shows no interchange with the methyl or carboxyl groups of the pyruvic acid. This can be explained if the reaction proceeds in two steps under the control of two different enzymes, $E_{1}$ and $E_{2}$ : $\mathrm{CH}_{3} \mathrm{CO} . \mathrm{COOH}+(\mathrm{CoA}) \cdot E_{1} \rightleftharpoons \mathrm{CH}_{3} \mathrm{CO} .(\mathrm{CoA}) E_{1}+$ $\mathrm{HCOOH}$

$\mathrm{CH}_{3} \mathrm{CO} .(\mathrm{CoA}) E_{1}+E_{2} \rightleftharpoons \mathrm{CH}_{3} \mathrm{CO}(\mathrm{CoA}) E_{2}+E_{1}$ $\mathrm{CH}_{3} \mathrm{CO}(\mathrm{CoA}) E_{2}+\mathrm{H}_{3} \mathrm{PO}_{4} \rightarrow \mathrm{CH}_{3} \mathrm{COO} . \mathrm{PO}_{3} \mathrm{H}_{2}+$

$$
\mathrm{CoA}+E_{2} \text {. }
$$

The coenzyme, CoA, is assumed to be present in all three reactions with appropriate changes in its state of oxidation-reduction.

Results are often misleading where they involve exchange across a cell membrane, as with the slow incorporation of phosphorus-32 into stimulated muscle (Sachs) as compared with its rapid exchange in muscle extracts; in the intact muscle the concentration of the internal inorganic phosphorus-32 is the important factor in limiting the uptake. Isotope dilution methods, if applied by adding unlabelled carrier intermediates to an intact cell suspension, are particularly prone to error.

Kaufman and Ochoa's work on the decarboxylation of labelled malic acid by $L$. arabinosus is an instructive example of another type of problem. Pyruvate, the intermediate between malate and lactate in this reaction, actually shows less activity than the lactate if unlabelled pyruvate is added to extract the active isotope. Here it appears that exchange between the carrier pyruvate and the enzyme-associated fraction is incomplete; the association persists in large part until the lactate is liberated at the end of the reaction.

Dr. J. L. Harley, working with Mr. C. C. McCready, reported on "The Phosphorus Uptake of Beech Mycorrhiza". An infection of the feeding rootlets by this fungal sheath, with its extensive outgrowing hyphæ, is apparently correlated with more rapid absorption of phosphorus (as well as of nitrogen and potassium) than in normal rootlets. Separation of the fungal sheath from the rootlet core showed that at low external concentrations of labelled phosphate, 90 per cent was retained in the sheath and only 10 per cent passed through into the core. The ratio could be reduced either by reducing the oxygen tension or by increasing the phosphate concentration, both of which favour passage into the core rather than into the sheath. Observations on slices of infected rootlets showed a potentially high rate of absorption of phosphorus-32 into the naked core, and were consistent with the assumption that penetration of phosphate normally takes place through the intercellufar spaces of the fungus, which remove the nutrients as they pass. It is evident that there is no foundation for the belief that the infection improves the nutrition of the host by an immediate and direct increase of phosphorus uptake. This, of course, does not preclude a possible secondary effect brought about by the seasonal regression of the nutrient-rich hyphal network.

A detailed study of "The Assimilation of Inorganic Phosphate by Micrococcus pyogenes var. aureus" was described by Dr. P. D. Mitchell. This work is com. parable with that of Spiegelmann on yeast; it represents an attempt to trace the pathways of phosphate radicals in bacterial suspensions. After equilibration with phosphate buffer, the suspensions were provided with added glucose for a period to determine the effect of glycolysis alone, or with glucose plus a casein hydrolysate to produce growth as well. Total and specific activities were determined for acid-soluble (inorganic and organic) fractions, lipid phosphorus, deoxyribonucleic acid and ribonucleic acid fractions as well as for an 'excess phosphate fraction' usually incorporated in and confused with the estimate of the ribonucleic acid. In the initial resting phase, uptake of phosphorus is found to be a one-way process, the phosphorus-32 accumulating in the acid-soluble inorganic fraction. The great increase in activity of this fraction during respiration and growth was ascribed by Dr. Mitchell, not to its high phosphorus turnover, but to its role as a precursor for all other phosphate fractions. From this precursor, acid-soluble organic phosphorus and lipid phosphorus are formed independently, together with a small amount of 'excess phosphate', the last two fractions showing a very small turnover-rate.

In the growth phase, the ribonucleic acid, deoxyribonucleic acid and excess phosphate all showed a considerable increase, the nucleic acid phosphorus passing through the acid-soluble fraction with little or no turnover. The lipid and excess phosphate fractions, on the other hand, show a high turnover in this phase. The rate of increase of deoxyribonucleic acid as compared with that of ribonucleic acid suggests that both must be built up independently from the acid-soluble organic fraction without the possibility of direct interconversion.

Prof. J. E. Harris's paper on "The Study of Phosphorus Uptake in Protozoa by Track Radiography" was concerned with a slightly different approach to microbiological problems, since the special autoradiographic method employed (the recording of individual $\beta$-tracks from organisms such as Paramecium caudatum) enables one to obtain a measure of individual differences in phosphorus-32 content between one organism and another. Since the total number of tracks per organism should not exceed 50 to avoid confusion in counting, statistical variation necessarily imposes a severe limitation on the accuracy of the method, which can, however, be successfully used at very low concentrations of radioactive phosphorus - as little as 10-20 atoms of phosphorus-32 per organism. Location of the origin of the tracks is possible to a limit of resolution of $5 \mu$, and the method can be used either on sections or on whole organisms, the latter suspended in congealed droplets of photographic emulsion. In a typical experiment, the distribution of phosphorus-32 among a population of Paramecium was found to be skewed, 
a few organisms showing counts much higher than the remainder. The nucleus did not show any excessive concentration of phosphorus-32. Most of the phosphorus enters from the food eaten, as shown by a low rate of uptake in the absence of bacterial suspensions, as well as by the high radioactivity of food vacuoles in the early stages of the digestive process.

Dr. J. E. Hotchin reviewed "The Use of Radioactive Phosphorus in Virus Studies", with particular reference to the metabolism of phosphorus compounds in virus-infected cells of different types. In effect, since the virus becomes part of the metabolic system of the host itself, this type of investigation links up with the study of the reproduction and metabolism of the virus particles themselves. Direct use of virus labelled with phosphorus-32 is theoretically practicable in the $B$. coli/1 2-phage system; an activity of $10 \mathrm{C}$. $/ \mathrm{gm}$. of phosphorus can be attained, equivalent to approximately 2 atoms of phosphorus-32 per virus particle.

The use of phosphorus-32 as a chemical method of detecting virus infection was illustrated by the work of Ward, who showed that the turnover of phosphorus in the allantoic fluid of the hen's egg increases ten to thirty times in virus-infected specimens.

Mr. J. H. Scott, under the title "Some Experiments with Radioisotopes and Algæ", gave a vivid account of the difficulties met with in the apparently simple problem of determining the extent of uptake of radioactive cerium and strontium from a circulating culture system containing the alga Cladophora crispata. While apologizing for the absence of results of this work, he nevertheless contributed a timely and useful warning of the difficulties of attempting to estimate radioisotope uptake by measuring the decrease in activity of the circulating liquid.

Describing "The Preparation of Radioactive Penicillin", Dr. E. Lester Smith commented on the problems of obtaining products of high activity by biological syntheses. Such compounds have considerable value in following the fate of antibiotics in an organism or even in the chemical handling and processing of the antibiotic itself. Biosynthetic methods, often extremely wasteful, are relatively efficient in the preparation of penicillin labelled with sulphur-35, where 10 per cent of the sulphur appears in the product. A minimum sulphur content of $0.1 \mathrm{mgm} . / \mathrm{ml}$. in the culture medium was required for optimum growth, and this demanded careful technique if the initial amount of sulphur-35 employed was to be kept within reasonable limits. A product having an activity of $0.74 \mu \mathrm{C}$. $/$ I. . was obtained.

Drs. P. D. Cooper, V. Few and D. Rowley gave a brief account of "The Uptake of Penicillin by Bacteria". The removal of unbound penicillin from bacteria or from bacterial cell walls by centrifuge washing and by electrodialysis showed that sensitive staphylococci bound 2-3 r.v./gm. dry-weight, while resistant organisms bound much less. This result was ascribed to the presence in the sensitive strains of a 'penicillin-binding compound', the reuction of which with the antibjotic is the initial step in the toxic process. Examination of the staphylococei after mechanical breakdown suggested that the penicillin-binding compound was associated with the cell wall; the amount present per cell appeared to increase when growth occurred in a penicillin medium.

The symposium was clearly designed to direct the attention of practising microbiologists to the possibilities of work with isotopes; such methods have already made a very substantial contribution to the biochemical side of the subject. How far such general meetings are of value now that this newest of analytical weapons has had a decade in which to establish its reputation may perhaps be doubted; the impression given was that most of the audience were already familiar with its potentialities. The extensive references to American work by all contributors prompt a rueful reflexion on the commanding lead which the United States has obtained in this field. Apart from the relatively late start in Great Britain, two reasons suggest themselves. The financial support for biological applications of the method is out of all proportion to the resources which are going into its physical development. Also, successful work with isotopes nearly always requires the participation of a team of workers with adequate technical assistance, and large-scale development of such researches makes heavy demands on man-power as well as money. These problems are not fully recognized in Great Britain, either in our training facilities or in our financial provision for biological research.

\section{NEWS and VIEWS}

Egyptology in University College, London: Mr. W. B. Emery

Mr. W. B. EMERY, who has recently been appointed professor of Egyptology at University College, London, is the leading and most experienced of the present generation of British excavators in Egypt. $\mathrm{H}_{\theta}$ was trained in the University of Liverpool Institute of Archæology under the late Prof. T. E. Peet, and, after a year as assistant secretary of the Institute, during 1923-24 had his first field experience in the excavations of the Egypt Exploration Society at Tell el Amarna. In 1924 he was appointed assistant to the late Sir Robert Mond, and during the next four years worked and excavated on his behalf in the Theban Necropolis. During these years Emery was also responsible for the consolidation and restoration of the Tomb of Ramose, and discovered and conducted the preliminary excavations of the tombs of the sacred Buchis bulls and their mothers at Armant. From 1929 until 1934 he was director of the Egyptian Government's Archæological Survey of Nubis, and found and excavated the barbaric but magnificent tombs of the X-Group kings and their followers at Ballana and Qustol. In 1935 he followed Quibell and Firth as director of the Egyptian Government's excavations at the Archaic Cemetery at Sakkara North. This is one of the most important sites in all Egypt, and Emery's work, unhappily interrupted by the Second World War, at once produced results of the highest importance and significance for the early history and architecture of Egypt. Though the matter is still undecided, it is possible that he has discovered the tombs of some at least of the kings of the First Dynasty. During and after the War, Emery had a distinguished record of service in the Western Desert and Cairo ; but hitherto it has been impossible for him to resume his excavations at 